\title{
PRE DIABETES IN YOUNG MEDICAL STUDENTS
}

\author{
Muaaz Waseem, ${ }^{1}$ Faraz Ahmed Bokhari, ${ }^{2}$ Muhammad Aakif Jalal ${ }^{3}$ \\ Zainab Zahra, ${ }^{4}$ Mahnoor Khalid, ${ }^{5}$ Maria Aman ${ }^{6}$
}

\begin{abstract}
Introduction: A study was conducted among students of a public medical college in Lahore, Pakistan to determine proportion of pre diabetic students (Blood sugar levels between $100 \mathrm{mg} / \mathrm{dl}-125 \mathrm{mg} / \mathrm{dl}$, accord-
\end{abstract}

Waseem M. ${ }^{1}$

Fourth Year MBBS Student

Sheikh Khalifa Bin Zayed Al-Nahyan Medical College,

Lahore

Bokhari F.A. ${ }^{2}$

Assistant Professor, Department of Physiology, Sheikh

Khalifa Bin Zayed Al-Nahyan Medical College, Lahore

Jalal M.A. ${ }^{3}$

Fourth Year MBBS Student

Sheikh Khalifa Bin Zayed Al-Nahyan Medical College,

Lahore

Zahra Z. ${ }^{4}$

Fourth Year MBBS Student

Sheikh Khalifa Bin Zayed Al-Nahyan Medical College,

Lahore

Khalid M. ${ }^{5}$

Fourth Year MBBS Student

Sheikh Khalifa Bin Zayed Al-Nahyan Medical College,

Lahore

Aman M. ${ }^{6}$

Fourth Year MBBS Student

Sheikh Khalifa Bin Zayed Al-Nahyan Medical College, Lahore ing to American Diabetes Association) and its relation with body mass index, family history of Diabetes, dietary habits, socioeconomic status and physical activity.

Methods: A cross sectional survey was conducted at Sheikh Zayed Medical Complex in February 2013 on medical students of either gender. Data was collected on a validated questionnaire. Fasting blood sugar levels of 65 students (enrolled after taking informed consent) were taken by trained co investigators through standardized glucose meter.

Results: A total of 65 medical students (43 males and 22 females) enrolled in this study. Their ages ranged from 18 to 23 years (mean age $20.56 \pm 0.97$ years). No student was found to be pre diabetic. Fasting blood sugar level in male participant with a family history of diabetes was significantly higher $(85 \pm 6.228$ vs. $79.857 \pm 6.602, \mathrm{P}=0.016$ ).

Conclusion: In this study, no student was found to be pre diabetic, though male participants with a family history of diabetes had higher fasting blood sugar levels. However, a larger study sample is required so that any significant finding may be shown, if it exists. Data on prevalence of pre-diabetes in youth in South Asia is scarce. The high incidence of diabetes in developing countries underlines the need to explore prevalence of pre diabetes in the younger population.

Key Words: Pre diabetes, Impaired Fasting Glucose (IFG). 


\section{Introduction}

Diabetes Mellitus (DM) is a leading cause of morbidity and mortality. Its silent nature, prolonged course and resulting complications affect quality of life of individuals. ${ }^{1} \mathrm{DM}$ has an impact on public health and puts a burden on already meager healthcare budgets of developing countries. Urbanization, physical inactivity and changing eating pattern are major factors linked with increased prevalence of $\mathrm{DM}^{2}$

A major concern is the emergence of Type 2 diabetes in children and young adolescents. ${ }^{3}$ It depends on the epidemiological status, non-modifiable factors like age and race, and / or modifiable risk factors like obesity and physical inactivity. DM can be asymptomatic till properly diagnosed and this asymptomatic period is known as pre diabetes - depicting that blood glucose is raised, but not enough to be diagnosed as diabetes. If detected early and steps taken to control risk factors, onset of overt DM and ensuing complications can be delayed or avoided. ${ }^{4}$ This study was conducted to elucidate the prevalence of pre-diabetes in the young adults in a local medical school.

\section{Methods}

This cross - sectional survey was conducted at Sheikh Zayed Medical Complex in February 2013. The students participating were from the undergraduate medical programme (MBBS) of either gender. A total of 65 students participated in this study; age range $(18-23$ years). Ethical approval was granted by the Institutional Review Board (IRB). A questionnaire to collect the appropriate data required was developed and validated. It included information about fast food consumption, levels of activity and family history of diabetes. Physical activity was determined by number of hours / day spent sedentary and exercise routine. Household income was asked to assess socioeconomic status.

Anthropometric measurements were taken. The techniques were corrected and re-tested until an acceptable level of variability in performance was reached.

Prior to data collection workshops were given on pre diabetes by the co-investigators to the respective three classes involved. They were briefed on what pre diabetes is, its pre valence in Pakistan, the significance of conducting this study and the eligibility criteria for the participants as for example students with pre-existing metabolic conditions and diseases could not participate.

A mechanical weighing machine was used with $0.5 \mathrm{~kg}$ accuracy. The height was recorded to the nearest centimeter. The body mass index (BMI) was calculated for each participant by taking weight in kilograms and height in meter square. A standardized glucose meter (Glucomonitor-N Blood Glucose Meter Model no: 4207) was used to measure blood sugar levels.

Informed consent was taken from each participant. The participants were then asked to fast overnight ( 8 hours or more). The blood glucose reading was taken in the morning (at around 8.00 am to $10.00 \mathrm{am}$ ).

The American Diabetes Association (ADA) classification was used as clinical criteria to diagnose pre diabetes: $\leq 100 \mathrm{mg} / \mathrm{dl}$ was considered normal blood glucose level and blood glucose $>100 \mathrm{mg} / \mathrm{dl}$ and $<126 \mathrm{mg} /$ dl was considered pre-diabetic (Blood sugar level $\geq 126 \mathrm{mg} / \mathrm{dl}$ was considered diabetic). ${ }^{5}$

\section{Results}

A total of 65 medical students (43 males and 22 females) participated in this study. Their ages ranged from 18 to 23 years (mean age $20.56 \pm 0.97$ years). No student was found to be pre diabetic. Detailed results are shown in Table 1, 2 and 3.

Fasting blood sugar level in male participant with a family history of diabetes was significantly higher ( $85 \pm 6.228$ vs. $79.857 \pm 6.602, \mathrm{P}=0.016$ ).

Table 1: Blood Sugar Level (BSL), Body - Mass Index (BMI) and their association with various risk factors in all participants. N: number of participants.

\begin{tabular}{|l|c|c|c|c|}
\hline & BSL & BSL - P value & N (mean BMI \pm STD) & BMI - P value \\
\hline Family History of Diabetes Mellitus & & & & \\
No & $23(82.044 \pm 6.609)$ & 0.086 & $20(22.837 \pm 3.505)$ & 0.310 \\
Yes & $42(85.238 \pm 7.726)$ & & $39(23.885 \pm 4.071)$ & \\
\hline
\end{tabular}


PRE DIABETES IN YOUNG MEDICAL STUDENTS

\begin{tabular}{|c|c|c|c|c|}
\hline & $\frac{\mathrm{BSL}}{\mathrm{N}(\text { mean BSL } \pm \mathrm{STD})}$ & $\mathrm{BSL}-\mathrm{P}$ value & $\begin{array}{c}\text { BMI } \\
\mathrm{N}(\text { mean BMI } \pm \text { STD })\end{array}$ & $\mathrm{BMI}$ - P value \\
\hline $\begin{array}{l}\text { No. of hours spent sedentary } \\
\text { Less than } 3 \text { hours } \\
\text { More than } 3 \text { hours }\end{array}$ & $\begin{array}{l}18(83.944 \pm 7.199) \\
46(84.174 \pm 7.715)\end{array}$ & 0.911 & $\begin{array}{l}15(22.805 \pm 3.582) \\
43(23.696 \pm 4.011)\end{array}$ & 0.430 \\
\hline $\begin{array}{l}\text { Exercise hours per week } \\
\text { Less than } 4 \\
\text { More than } 4\end{array}$ & $\begin{array}{l}44(85.000 \pm 7.838) \\
19(82.263 \pm 6.674)\end{array}$ & 0.165 & $\begin{array}{l}41(23.364 \pm 4.025) \\
16(23.843 \pm 3.740)\end{array}$ & 0.674 \\
\hline $\begin{array}{l}\text { No. of restaurant visits } \\
\text { Less than twice per week } \\
\text { More than twice a week }\end{array}$ & $\begin{array}{l}44(84.456 \pm 7.066) \\
21(83.191 \pm 8.328)\end{array}$ & 0.524 & $\begin{array}{l}42(24.041 \pm 4.127) \\
17(22.264 \pm 2.970)\end{array}$ & 0.072 \\
\hline $\begin{array}{l}\text { Monthly income(PKR) } \\
\text { Less than } 50,000 \\
\text { More than } 50,000\end{array}$ & $\begin{array}{l}19(82.737 \pm 6.657) \\
46(84.674 \pm 7.763)\end{array}$ & 0.316 & $\begin{array}{l}17(23.412 \pm 4.380) \\
42(23.577 \pm 3.730)\end{array}$ & 0.892 \\
\hline
\end{tabular}

Table 2: Blood Sugar Level (BSL), Body - Mass Index (BMI) and their association with various risk factors in male participants. N: number of participants.

\begin{tabular}{|c|c|c|c|c|}
\hline & $\begin{array}{c}\text { BSL } \\
\mathrm{N}(\text { mean BSL } \pm \text { STD })\end{array}$ & $\mathrm{BSL}-\mathrm{P}$ value & $\begin{array}{c}\text { BMI } \\
\mathrm{N}(\text { mean BMI } \pm \text { STD })\end{array}$ & BMI - P value \\
\hline $\begin{array}{l}\text { Family History of DM } \\
\text { No } \\
\text { Yes }\end{array}$ & $\begin{array}{c}14(79.857 \pm 6.602) \\
29(85 \pm 6.228)\end{array}$ & 0.016 & $\begin{array}{l}13(22.461 \pm 3.200) \\
27(23.971 \pm 3.458)\end{array}$ & 0.185 \\
\hline $\begin{array}{l}\text { No. of hours spent sedentary } \\
\text { Less than } 3 \text { hours } \\
\text { More than } 3 \text { hours }\end{array}$ & $\begin{array}{l}14(83.930 \pm 5.980) \\
29(80.035 \pm 6.920)\end{array}$ & 0.666 & $\begin{array}{l}12(23.315 \pm 2.857) \\
28(23.550 \pm 3.670)\end{array}$ & 0.829 \\
\hline $\begin{array}{l}\text { Exercise hours per week } \\
\text { Less than } 4 \\
\text { More than } 4\end{array}$ & $\begin{array}{l}29(84.103 \pm 6.494) \\
13(81.846 \pm 6.926)\end{array}$ & 0.331 & $\begin{array}{l}27(23.873 \pm 3.846) \\
12(22.863 \pm 2.297)\end{array}$ & 0.341 \\
\hline $\begin{array}{l}\text { No. of restaurant visits } \\
\text { Less than twice per week } \\
\text { More than twice a week }\end{array}$ & $\begin{array}{c}25(83.429 \pm 6.665) \\
18(83.5 \pm 6.555)\end{array}$ & 0.884 & $\begin{array}{l}25(24.201 \pm 3.407) \\
15(22.278 \pm 3.169)\end{array}$ & 0.080 \\
\hline $\begin{array}{l}\text { Monthly income(PKR) } \\
\text { Less than 50,000 } \\
\text { More than 50,000 }\end{array}$ & $\begin{array}{l}14(83.429 \pm 6.665) \\
29(83.276 \pm 6.643)\end{array}$ & 0.944 & $\begin{array}{l}13(22.642 \pm 3.861) \\
27(23.883 \pm 3.171)\end{array}$ & 0.326 \\
\hline
\end{tabular}

Table 3: Blood Sugar Level (BSL), Body - Mass Index (BMI) and their association with various risk factors in female participants. N: number of participants.

\begin{tabular}{|l|c|c|c|c|}
\hline & BSL & BSL - P value & N (mean BMI \pm STD) & BMI - P value \\
\hline $\begin{array}{l}\text { Family History of DM } \\
\text { No }\end{array}$ & $9(85.444 \pm 6.247)$ & 0.929 & $7(23.535 \pm 4.189)$ & 0.945 \\
Yes & $13(85.769 \pm 10.631)$ & & $12(23.691 \pm 5.377)$ & \\
\hline
\end{tabular}




\begin{tabular}{|l|c|c|c|c|}
\hline & $\begin{array}{c}\text { BSL } \\
\text { N (mean BSL } \pm \text { STD })\end{array}$ & BSL - P value & $\begin{array}{c}\text { BMI } \\
\text { N (mean BMI } \pm \text { STD })\end{array}$ & BMI - P value \\
\hline $\begin{array}{l}\text { No. of hours spent sedentary } \\
\text { Less than 3 hours } \\
\text { More than 3 hours }\end{array}$ & $\begin{array}{c}4(84.000 \pm 11.776) \\
17(86.118 \pm 8.788)\end{array}$ & 0.753 & $3(20.776 \pm 6.096)$ & 0.466 \\
\hline $\begin{array}{l}\text { Exercise hours per week } \\
\text { Less than 4 } \\
\text { More than 4 }\end{array}$ & $\begin{array}{c}15(86.733 \pm 9.975) \\
6(83.167 \pm 6.616)\end{array}$ & 0.355 & $\begin{array}{c}14(22.480 \pm 4.358) \\
4(26.783 \pm 5.936)\end{array}$ & 0.249 \\
\hline $\begin{array}{l}\text { No. of restaurant visits } \\
\text { Less than twice per week } \\
\text { More than twice a week }\end{array}$ & $\begin{array}{c}19(86.316 \pm 7.303) \\
3(81.333 \pm 17.954)\end{array}$ & 0.680 & $\begin{array}{c}17(23.807 \pm 5.112) \\
2(22.162 \pm 0.732)\end{array}$ & 0.240 \\
\hline $\begin{array}{l}\text { Monthly income(PKR) } \\
\text { Less than 50,000 }\end{array}$ & $5(80.800 \pm 6.979)$ & 0.138 & $4(25.915 \pm 5.636)$ & 0.397 \\
\hline More than 50,000 & $17(87.059 \pm 9.093)$ & & $15(23.025 \pm 4.643)$ & \\
\hline
\end{tabular}

\section{Discussion}

The increase in incidence of diabetes in developing countries is expected to be much more than in developed countries ( $170 \%$ vs. $42 \%$ over 1995 - 2025 year period). ${ }^{6}$ An alarming factor is the incidence of diabetes in youth. According to a 2006 research, 35\% of US adults, aged 20 years or older, had pre diabetes, in addition to about 2.8 million adolescents who were also found to have the same. ${ }^{7}$ In China, a 2010 study estimated that 92.4 million adults (20 years of age or older) had diabetes. In addition, 148.2 million adults $(15.5 \%)$ had pre diabetes and the prevalence, in ages $20-39$ years, of diabetes and pre diabetes was $3.2 \%$ and $9.0 \%$ respectively. $^{8}$ In a 2002 survey, the overall diabetes prevalence in Australia was $7.4 \%$, and an additional $16.4 \%$ had pre diabetes. In the youngest age group in that study ( $25-34$ years), $5.7 \%$ of subjects had abnormal glucose tolerance. ${ }^{9}$ A 2006 study estimated the numbers of Korean adults (aged $>20$ years) with diabetes or IFG to be 2.6 and 8.1 million, respectively. ${ }^{10}$

The situation in South Asia is not different. In Sri Lanka a survey showed one in five adults to have either diabetes or pre-diabetes. ${ }^{11}$ A study by Indian Council of Medical Research (ICMR - INDIAB) predicted that by 2011, 4 major Indian states would have 0.13 to 9.2 million people suffering from pre diabetes, while it projected that 77.2 million people would contract pre diabetes in the whole of India. ${ }^{12}$

A study in a selected urban population of Rawalpindi, Pakistan showed $5.61 \%$ prevalence of pre-diabetes overall and $0.88 \%$ prevalence in the youth speci- fically ( $\leq 25$ years). ${ }^{13}$

The role of family history as a risk for diabetes is also well established. A history of both Type 1 and Type 2 Diabetes Mellitus $\left(\mathrm{T}_{2} \mathrm{DM}\right)$, have an effect on phenotype of patients with $\mathrm{T}_{2} \mathrm{DM}$ suggesting a genetic interaction between both types ${ }^{14}$ and in the present study, blood sugar level was notably higher in male participants with family history of diabetes. In females, however, similar trend was not observed possibly due to smaller sample size.

'The prevalence of isolated impaired glucose tolerance (i-IGT) is higher in women than in men, whereas the prevalence of isolated impaired fasting glycaemia (i-IFG) is higher in men than in women'. ${ }^{15}$ In our study we didn't find any pre diabetic or with impaired fasting glycaemia.

The data on prevalence in youth $(18-25$ years $)$ is scarce. If we look at Asia, in China, the prevalence of IFG in $20-39$ years is $9.0 \% .^{8}$ A study on 280 overweight Japanese children showed $19.2 \%$ prevalence of pre diabetes. ${ }^{16}$ The project of Rawalpindi showed $0.88 \%$ prevalence in the youth $(\leq 25$ years $) .{ }^{13}$ There was also a research done on school-going children in India (aged 5 - 10 years) which showed a $3.7 \%$ prevalence of pre diabetes. ${ }^{17}$

The biggest limitation of this study was its sample size and setting. A large sample from different colleges may show significant findings about the status of pre diabetes and diabetes in young medical students. In addition, inclusion of Oral Glucose Tolerance Test can give more convincing findings. Data on prevalence of pre diabetes in youth in South Asia is scarce. The high incidence of diabetes in developing countries under- 
lines the need to explore prevalence of pre diabetes in the younger population, so that appropriate screening programs could be developed and lifestyle changes be addressed.

\section{References}

1. American Diabetes Association. Diagnosis and classification of diabetes mellitus. Diabetes care, 2011; 34 Suppl 1: S62-9.

2. National Diabetes Data Group. Classification and diagnosis of diabetes mellitus and other categories of glucose intolerance. Diabetes, 1979; 28 (12): 1039-57.

3. Knowler WC, Barrett-Connor E, Fowler SE, Hamman RF, Lachin JM, Walker EA, et al. Reduction in the incidence of type 2 diabetes with lifestyle intervention or metformin. N Engl J Med. 2002; 346 (6): 393-403.

4. Ackermann RT, Cheng YJ, Williamson DF, Gregg EW. Identifying adults at high risk for diabetes and cardiovascular disease using hemoglobin A1c National Health and Nutrition Examination Survey 2005 - 2006. Am J Prev Med. 2011; 40 (1): 11-7.

5. American Diabetes Association. Diagnosis and classification of diabetes mellitus. Diabetes care, 2012; 35 Suppl 1: S64-71.

6. King H, Aubert RE, Herman WH. Global burden of diabetes, 1995 - 2025: prevalence, numerical estimates, and projections. Diabetes care, 1998; 21 (9): 1414-31.

7. Duncan GE. Prevalence of diabetes and impaired fasting glucose levels among US adolescents: National Health and Nutrition Examination Survey, 1999 - 2002. Arch Pediatr Adolesc Med. 2006; 160 (5): 523.

8. Yang W, Lu J, Weng J, Jia W, Ji L, Xiao J, et al. Prevalence of diabetes among men and women in China. $\mathrm{N}$ Engl J Med. 2010; 362 (12): 1090-101.

9. Dunstan DW, Zimmet PZ, Welborn TA, De Courten MP, Cameron AJ, Sicree RA, et al. The rising preva- lence of diabetes and impaired glucose tolerance: the Australian Diabetes, Obesity and Lifestyle Study. Diabetes care, 2002; 25 (5): 829-34.

10. Kim SM, Lee JS, Lee J, Na JK, Han JH, Yoon DK, et al. Prevalence of diabetes and impaired fasting glucose in Korea: Korean National Health and Nutrition Survey 2001. Diabetes care, 2006; 29 (2): 226-31.

11. Katulanda P, Constantine GR, Mahesh JG, Sheriff R, Seneviratne RD, Wijeratne S, et al. Prevalence and projections of diabetes and pre-diabetes in adults in Sri Lanka--Sri Lanka Diabetes, Cardiovascular Study (SLDCS). Diabet Med. 2008; 25 (9): 1062-9.

12. Anjana RM, Pradeepa R, Deepa M, Datta M, Sudha V, Unnikrishnan R, et al. Prevalence of diabetes and prediabetes (impaired fasting glucose and/or impaired glucose tolerance) in urban and rural India: phase I results of the Indian Council of Medical Research - India Diabetes (ICMR -INDIAB) study. Diabetologia. 2011; 54 (12): 3022-7.

13. Zafar J, Bhatti F, Akhtar N, Rasheed U, Bashir R, Humayun S, et al. Prevalence and risk factors for diabetes mellitus in a selected urban population of a city in Punjab. J Pak Med Assoc. 2011; 61 (1): 40-7.

14. Li H, Isomaa B, Taskinen MR, Groop L, Tuomi $\mathrm{T}$. Consequences of a family history of type 1 and type 2 diabetes on the phenotype of patients with type 2 diabetes. Diabetes care, 2000; 23 (5): 589-94.

15. Faerch K, Borch - Johnsen K, Vaag A, Jorgensen T, Witte DR. Sex differences in glucose levels: a consequence of physiology or methodological convenience? The Inter99 study. Diabetologia. 2010; 53 (5): 858-65.

16. Ramachandran A, Snehalatha C, Satyavani K, Sivasanakri S, Vijay V. Type 2 diabetes in Asian Indian urban children. Diabetes Care, 2003; 26: 1022-5.

17. Narayanappa D, Rajani HS, Mahendrappa KB, Prabhakar AK. Prevalence of prediabetes in school-going children. Indian Pediatr. 2011; 48 (4): 295-9. 